\title{
Aspergillus Fumigatus pada Sputum Penderita Batuk Kronik Menggunakan Metode PCR dan Kultur
}

\author{
Isra Thristy, ${ }^{1}$ Yahwardiah Siregar, ${ }^{2}$ \\ ${ }^{1}$ Magister Ilmu Biomedik Fakultas Kedokteran Universitas Sumatera Utara, ${ }^{2}$ Departemen Biokimia Fakultas \\ Kedokteran Universitas Sumatera Utara
}

\begin{abstract}
Abstrak
Kecepatan tumbuh jamur yang bertambah pada manusia dapat terjadi akibat berbagai penggunaan obat-obatan, alat-alat kesehatan invasif, juga terdapat faktor predisposisi berupa penyakit kronik yang berat termasuk penyakit keganasan. Aspergilus fumigatus merupakan salah satu spesies jamur sistemik yang dapat menginfeksi manusia. Penggunaan polymerase chain reaction (PCR) untuk mendeteksi jamur merupakan diagnostik yang optimal. Tujuan penelitian ini adalah menganalisis Aspergillus fumigatus menggunakan PCR dan kultur pada sputum penderita batuk kronik. Penelitian ini menggunakan 51 sampel sputum penderita batuk kronik yang berasal dari Rumah Sakit Haji Adam Malik Medan, periode Mei 2012-Februari 2013 diteliti dengan metode deskriptif crosssectional. Sputum diperiksa menggunakan metode PCR dan dilakukan kultur sebagai gold standard pemeriksaan jamur. Hasil penelitian dari 51 sampel didapatkan pemeriksaan PCR positif 35 sampel (69\%) dan PCR negatif 16 sampel (31\%). Pada hasil kultur dijumpai kultur positif 29 sampel (57\%) dan kultur negatif 22 sampel (43\%). Simpulan dari hasil penelitian ini adalah dari 51 sputum penderita batuk kronik ternyata $69 \%$ mengandung jamur Aspergillus fumigatus dan keadaan ini diperkuat dengan hasil kulturnya. Pemeriksaan PCR dapat dipergunakan sebagai salah satu pemeriksaan jamur yang cepat dan tepat. [MKB. 2016;48(2):78-83]
\end{abstract}

Kata kunci: Aspergillus fumigatus, batuk kronis, kultur, PCR

\section{Aspergillus Fumigatus in Sputum of Patients with Chronic Cough Using PCR and Culture Method}

\begin{abstract}
The increasing prevalence of fungal growth in humans may occur as a result of the use of various drugs, invasive medical devices, and also the presence of predisposing factors like severe chronic diseases, including malignant disease. Aspergillus fumigatus is a systemic fungal species that can infect human beings. Polymerase chain reaction (PCR) is the most optimum diagnostic method to detect fungus. The purpose of this study was to analyze the presence of Aspergillus fumigatus by using PCR and culture method in sputum of patients with chronic cough. The sample of this study consisted of sputum from 51 patients who visited Haji Adam Malik Hospital in Medan. The examination applied the cross-sectional descriptive method. Sputum was examined using PCR and culture as the gold standard fungal examination. The results from the 51 samples showed that positive PCR results (69\%) were found in 35 patients and negative results were found in 16 patients (31\%). The culture results showed that positive cultures were seen in 29 samples (57\%) and negative cultures were found in 22 samples (49\%). it is concluded that from 51 patients with chronic cough sputum, $69 \%$ turn out to have Aspergillus fumigatus fungus and this result is reinforced by the culture results. PCR can be used as a quick and precise inspection method for detecting fungus. [MKB. 2016;48(2):78-83]
\end{abstract}

Key words: Aspergillus fumigatus, chronic cough, culture, PCR

Korespondensi: Isra Thristy, dr., Magister Ilmu Biomedik Fakultas Kedokteran Universitas Sumatera Utara, Jalan Dr. T. Mansur No.5, Kampus USU, Medan 20155, mobile 08126330780, e-mail isra_thristy@yahoo.com 


\section{Pendahuluan}

Batuk merupakan suatu mekanisme refleks yang sangat penting untuk menjaga jalan napas agar tetap terbuka dengan cara menyingkirkan hasil sekresi lendir yang menumpuk, gumpalan darah dan benda asing pada jalan napas, selain itu batuk juga dapat disebabkan oleh iritasi jalan napas. ${ }^{1}$ Batuk karena iritasi pada mukosa bronkus disebabkan oleh peradangan, baik oleh bakteri, virus, dan jamur disertai dengan mukus yang banyak. ${ }^{2}$

Akhir-akhir ini perhatian terhadap penyakit mikosis paru semakin meningkat dan kejadian infeksi jamur paru semakin sering dilaporkan. Bertambahnya kecepatan tumbuh jamur sebagai akibat cara pengobatan yang modern, terutama penggunaan antibiotik berspektrum luas atau kombinasi berbagai antibiotik, penggunaan kortikosteroid dan obat imunosuppresif lainnya, serta penggunaan sitostatika dan terdapat faktor predisposisi, yaitu penyakit kronik yang berat termasuk penyakit kegananasan. ${ }^{3}$

Angka kekerapan mikosis paru di dunia dan di Indonesia belum diketahui secara pasti, hal ini akibat sulitnya mendiagnosis mikosis paru karena permasalahannya adalah gambaran klinis maupun radiologik penderita mikosis paru tidak khas. Selain itu, sediaan apus sputum, biakan jamur, pemeriksaan histologik paru, dan uji serologik pun kadang hasilnya membingungkan sehingga pengobatan infeksi jamur paru sering terlambat. $^{3}$

Diketahui ada beberapa spesies jamur yang dapat menginfeksi manusia, namun penyebab infeksi pada paru-paru 90\% adalah Aspergilus fumigatus. ${ }^{4}$ Jamur oportunistik yang paling sering menyebabkan infeksi jamur invasif adalah Candida albicans, Candida spp., dan Aspergillus spp. $^{5}$

Penelitian terhadap bilasan bronkus pada penderita tuberkulosis paru yang telah sembuh di RS Haji Adam Malik Medan didapatkan 11 kasus $(21,5 \%)$ jamur paru dari 40 penderita yang terdiri atas Candida sp. 7 penderita $(63,6 \%)$, Aspergillus fumigatus 3 penderita $(27,3 \%)$, dan Aspergillus niger seorang penderita (9,1\%). Dari penelitian ini, gejala klinis yang paling sering terjadi pada kasus infeksi jamur positif adalah batuk kronik yang berdahak dan batuk darah. ${ }^{3}$

Menurut penelitian yang dilakukan di India pada tahun 2002 sampai 2003 dengan kultur sputum pasien yang positif tuberkulosis paru kronik dan telah mendapatkan pengobatan, didapatkan bahwa dari 500 pasien dijumpai 200 pasien yang menderita infeksi jamur (46\%).
Jenis jamur yang terbanyak adalah Aspergillus fumigatus, Aspergillus niger, Histoplasma capsulatum, dan Cryptococcus neoforman. ${ }^{6}$

Banyak penelitian yang telah dilaporkan untuk mendeteksi asam nukleat Aspergillus dengan PCR untuk memperbaiki diagnosis invasif aspergilosis, baik yang berasal dari cairan BAL, serum darah, dan sputum. ${ }^{6}$ Penggunaan PCR menjadi standar dan juga valid dalam pemeriksaan laboratorium untuk menegakkan diagnosis aspergilosis invasif secara cepat. ${ }^{7}$ PCR menggunakan cairan BAL memiliki sensitivitas 67-100\% dan spesifisitasnya 55-95\% untuk invasive pulmonary Aspergillosis. Sampel serum memiliki sensitivitas $100 \%$ dan spesifisitas $65-$ 92\%. ${ }^{8,9}$ Penggunaan PCR untuk mendeteksi asam nukleat jamur mungkin merupakan diagnostik yang optimal karena memiliki potensial lebih sensitif daripada metode kultur pada berbagai spesimen. ${ }^{6}$ Deteksi $A$. fumigatus menggunakan PCR dari hasil kultur murni lebih cepat dengan waktu kurang dari satu hari dibanding dengan analisis kultur yang memakan waktu berharihari. ${ }^{10}$ Selain itu, diagnosis melalui kultur, PAS stain, pewarnaan imunohistokimia sulit dilakukan, dan juga kultur Aspergillus spp. tidak dapat membuktikan suatu infeksi. ${ }^{11}$ Metode PCR terbukti lebih sensitif daripada deteksi antigen jamur Aspergillus. ${ }^{12}$

Penelitian jamur pada nasal lavage yang dilakukan kultur dan PCR ditemukan bahwa hasilnya dengan kultur ditemukan $25 \%$ positif jamur dan juga dengan PCR $44 \%$ positif jamur. Penelitian pada 108 sputum pasien cystic fibrosis untuk mendeteksi Aspergillus dengan metode kultur dan PCR didapatkan 30\% positif jamur Aspergillus dengan kultur dan $80 \%$ positif Aspergillus dengan metode PCR. ${ }^{13}$

Aspergillus fumigatus dan kelompok Mucor paling sering mencapai susunan saraf pusat melewati paru sekitar 50\%. Angka kematian akibat penyakit ini cukup tinggi, yaitu 30-40\% serta insidensinya meningkat seiring dengan pemakaian obat imunosupresif dan penurunan daya tahan tubuh. Manifestasi infeksi jamur dan parasit pada susunan saraf pusat dapat berupa meningitis dan proses desak ruang (abses atau kista). ${ }^{14}$

Dengan latar belakang tersebut maka peneliti bertujuan menganalisis Aspergillus fumigatus menggunakan polymerase chain reaction (PCR) serta kultur pada sputum penderita batuk kronik. Diharapkan dengan hasil penelitian ini dapat memberikan informasi ilmiah kepada para klinisi umum dan klinisi ilmu penyakit paru mengenai kemungkinan penderita batuk 
kronik mengalami infeksi jamur paru. Selain itu, dapat diaplikasikan dan menjadi pilihan metode dalam mendeteksi infeksi jamur dengan cepat dan tepat bila fasilitas mendukung, dan dapat memberikan motivasi peneliti lain untuk meneliti infeksi jamur di Indonesia mengingat kawasan Indonesia merupakan daerah tropis.

\section{Metode}

Desain penelitian ialah deskriptif cross sectional. Penelitian dilaksanakan mempergunakan teknik polymerase chain reaction (PCR) dan kultur. Penelitian ini telah mendapatkan persetujuan dari Komisi Etik Penelitian Bidang Kesehatan Fakultas Kedokteran Universitas Sumatera Utara. Penelitian dilakukan di laboratorium terpadu Fakultas Kedokteran Universitas Sumatera Utara dan laboratorium Mikrobiologi Fakultas Kedokteran Universitas Islam Sumatera Utara. Populasi penelitian ini adalah penderita batuk kronik yang berobat ke poliklinik paru Rumah Sakit Haji Adam Malik Medan. Sampelnya adalah sputum dari penderita batuk kronik. Kriteria inklusi adalah penderita batuk yang lebih dari tiga minggu, penderita batuk yang disertai dahak, dan penderita yang berusia 17 tahun ke atas. Kriteria eksklusi adalah penderita yang telah terdiagnosis menderita penyakit jamur, dan lokal maupun sistemik, penderita batuk kronik yang mendapatkan pengobatan antijamur, dan penderita batuk kronik yang tidak dapat mengeluarkan dahak (sputum). Sampel sputum yang didapat dari pasien dibagi dua, yaitu untuk pemeriksaan PCR dan pemeriksaan kultur.

Metode kultur yang dipergunakan adalah mempelajari koloni jamur yang diperhatikan pertumbuhannya pada media miring Sabouraud dextrose agar. Ambil $10 \mu \mathrm{L}$ sputum menggunakan sengkelit. Arsir pada pemukaaan media miring Sabouroud dextrose agar. Eramkan pada suhu kamar $\left(26-28^{\circ} \mathrm{C}\right)$ selama 10 hari. Interpretasi hasil koloni Aspergillus fumigatus jika pada permukaan media ditemukan pertumbuhan filamen putih yang setelah itu memproduksi spora seperti beledru dengan warna putih keabu-abuan.

Rendam inokulum (mounting) dalam larutan lactophenol cotton-blue, lalu ditutup dengan sebuah gelas penutup (deck glass). Periksa di bawah mikroskop pembesaran 10. Interpretasi hasilnya. Positif jamur Aspergillus fumigatus bila dijumpai hifa bersepta (konidiopora) dan membentuk konidia (spora).

Isolasi DNA dilakukan menggunakan bahan yang berasal dari pabrik Promega. $900 \mu \mathrm{L}$ cell lysis solution dimasukkan kedalam tabung 1,5 $\mathrm{mL}$ dan ditambahkan $300 \mu \mathrm{L}$ sampel sputum. Tabung dibalikkan 5-6 kali agar larutan dapat tercampur. Tabung diinkubasi selama 10 menit pada temperatur ruangan (selama inkubasi balikkan tabung 2-3 kali), lalu disentrifugasi dengan kecepatan 13.000-16.000 rpm selama 20 detik pada temperatur ruangan. Supernatannya dibuang, dan divorteks selama 10-15 detik. Setelah itu, ke dalam tabung itu ditambahkan $300 \mu \mathrm{L}$ nuclei lysis solution dan larutannya dipipet 5-6 kali untuk memecahkan dinding jamur. Kemudian ditambahkan $100 \mu \mathrm{L}$ protein precipitation solution, dan divorteks selama 1020 detik. Supernatannya dipindahkan ke tabung 1,5 mL steril baru yang sebelumnya telah diisi dengan isopropanol $300 \mu \mathrm{L}$. Tabung disentrifus dengan kecepatan 13.000-16.000 rpm selama 3 menit pada temperatur ruangan. Larutannya diaduk dengan membalikkan tabung hingga terlihat benang-benang putih halus DNA. Tabung disentrifus dengan kecepatan 13.000-16.000 rpm selama 3 menit pada temperatur ruangan, hingga dapat terlihat pellet pada dasar tabung. Supernatannya dibuang, dan juga ditambahkan $300 \mu \mathrm{L}$ etanol $70 \%$. Tabung dibalik agar pellet dan larutan tercampur lalu disentrifus dengan kecepatan 13.000-16.000 rpm selama 3 menit pada temperatur ruangan. Secara perlahan etanol dibuang dengan pipet. Tabung dibalikkan di atas kertas absorben dan pellet dikeringkan selama 10-15 menit. Terakhir ditambahkan 50 $\mu \mathrm{L}$ DNA rehydration solution ke dalam tabung. DNA disimpan selama semalam pada suhu $4^{\circ} \mathrm{C}$, lalu DNA disimpan pada suhu $2-8^{\circ} \mathrm{C}$.

PCR dilakukan dua tahap mempergunakan 2 (dua) pasang primer yang berbeda (Tabel 1) karena fragmen yang diharapkan cukup pendek. Tahapan PCR pertama dimaksudkan untuk meningkatkan jumlah DNA cetakan pada PCR tahap kedua. Proses PCR tahap pertama mempergunakan pasangan primer AFU7S dan AFU7AS mengamplifikasi region 18S rRNA. Dengan ukuran fragmen $405 \mathrm{bp}$ dan target PCR kedua menggunakan pasangan primer AFU5S dan AFU5AS yang akan menghasilkan produk DNA dengan ukuran fragmen internal $236 \mathrm{bp}$ (Gambar 1).

Setiap $25 \mu \mathrm{L}$ campuran PCR, sekitar 50$150 \mathrm{ng}$ total DNA digunakan sebagai template. Langkah pertama PCR menggunakan primer AFU7S-AFU7AS, langkah kedua mempergunakan primer AFU5S-AFU5AS. PCR dengan memakai metode Thermal Cycler (Perkin-Elmer Catus), dengan urutan: PCR pertama, prosesnya 2 
Tabel 1 Sequencing Nukleotida Pasangan Primer yang Digunakan Pada PCR

\begin{tabular}{llc}
\hline \multicolumn{1}{c}{ Primer } & \multicolumn{1}{c}{ DNA Sequence (5'-3') } & Lokasi \\
\hline AFU5S & AGG GCC AGC GAG TAC ATC ACC TTG & $1436-1459$ \\
AFU5AS & GG G (AG)GT CGT TGC CAA C(CT)C (CT)CC TGA & $1648-1771$ \\
AFU7S & CGG CCC TTA AAT AGC CCG & $1296-1313$ \\
AFU7AS & GA CCG GGT TTG ACC AAC TTT & $1681-1700$ \\
\hline
\end{tabular}

menit pada suhu $94^{\circ} \mathrm{C}$, kemudian dilakukan sebanyak 35 siklus selama 40 detik pada suhu $94^{\circ} \mathrm{C}, 1$ menit pada $60^{\circ} \mathrm{C}$, dan 1 menit pada $72^{\circ} \mathrm{C}$, dengan langkah terakhir 5 menit pada $72^{\circ} \mathrm{C}$ dan kemudian hasilnya disimpan pada suhu $4^{\circ} \mathrm{C}$. PCR kedua menggunakan produk hasil dari PCR pertama sebanyak $10 \mu \mathrm{L}$. Prosesnya 2 menit pada suhu $94^{\circ} \mathrm{C}$ dan kemudian 45 siklus selama 40 detik pada suhu $94^{\circ} \mathrm{C}, 1$ menit pada suhu $60^{\circ} \mathrm{C}$, 1 menit pada suhu $72^{\circ} \mathrm{C}$, serta langkah terakhir 5 menit pada $72^{\circ} \mathrm{C}$ dan kemudian hasilnya disimpan pada suhu $4^{\circ} \mathrm{C}$.

Hasil PCR dipisahkan memakai 2\% agarose gel electrophoresis dan diwarnai dengan etidium bromid. Gel dimasak dan didinginkan pada suhu $50-60^{\circ} \mathrm{C}$ setelah penambahan etidium bromid dengan konsentrasi $0,5 \mu \mathrm{g} / \mathrm{mL}$, gel dibiarkan mengeras lebih kurang selama 15 menit. Kemudian diletakkan pada tank electrophoresis dengan 1x TAE bufer. Elektroforesis dijalankan pada tegangan $70 \mathrm{~V}$ selama 1 jam. ${ }^{15}$

DNA hasil amplifikasi tersebut yang telah dielektroforesis divisualisasi menggunakan gel documentation. Pita DNA akan terlihat dan dapat diketahui ukurannya berdasarkan atas penanda ukuran molekul yang dinyatakan dengan base pair. Dengan intepretasi hasil negatif jika tidak terbentuk band atau terbentuk pita berukuran di atas atau di bawah 236 bp dan positif jika terbentuk pita berukuran $236 \mathrm{bp}$.

\section{Hasil}

Pengumpulan sampel dilaksanakan di Poli Paru Rumah Sakit Haji Adam Malik Medan. Jumlah semua sampel sebanyak 51 orang penderita batuk kronik. Dari seluruh sampel didapatkan pasien laki-laki sebanyak 29 orang (57\%) dan perempuan 22 orang (43\%). Pada penelitian ini pasien yang paling muda berusia 17 tahun, sedangkan yang paling tua berusia 70 tahun. Dengan menggunakan teknik PCR didapatkan hasil positif sebanyak 35 orang (69\%) dan negatif 16 orang (31\%) (Tabel 2).

Semua yang diperiksa menggunakan teknik two step PCR untuk mendeteksi DNA jamur Aspergillus fumigatus. Hasil produk PCR dianalisis menggunakan elektroforesis gel agarosa $2 \%$. Pada setiap gel diberikan marker, kontrol positif,

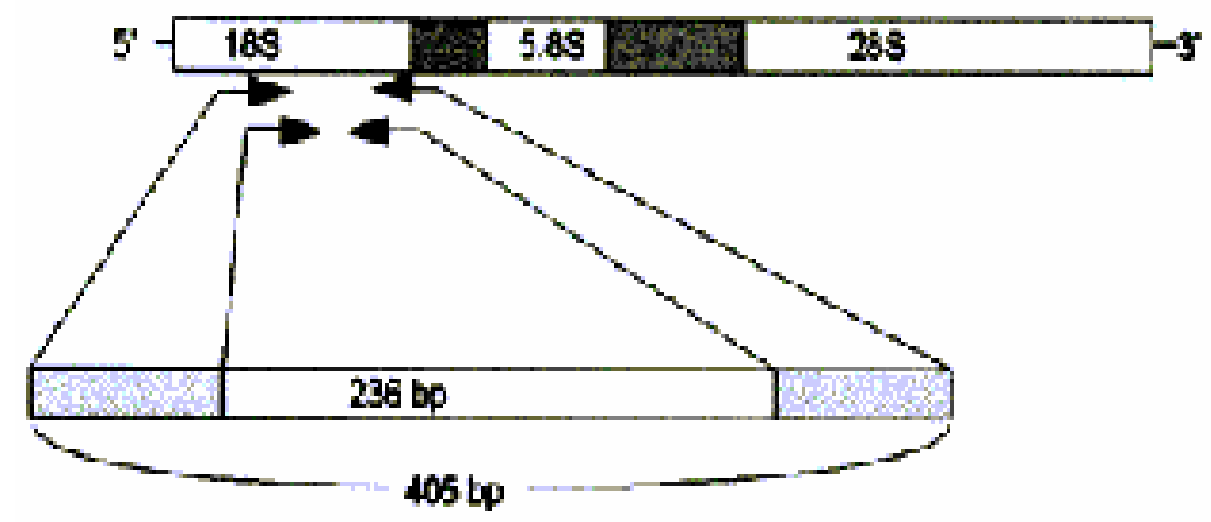

Gambar 1 Lokasi Pasangan Primer AFU5S-AFU5AS (236 bp) dan AFU7S-AFU7AS (405 bp) yang Dihasilkan Menggunakan PCR Dua Tahap dalam Mendeteksi DNA Aspergillus fumigatus 
Tabel 2 Distribusi Hasil PCR dan Kultur pada Pemeriksaan Sputum

\begin{tabular}{ccc}
\hline Variabel & $\begin{array}{c}\text { Jumlah } \\
\text { (orang) }\end{array}$ & $\begin{array}{c}\text { Persentase } \\
\text { (\%) }\end{array}$ \\
\hline Hasil PCR & & \\
Positif & 35 & 69 \\
Negatif & 16 & 31 \\
Jumlah & 51 & 100 \\
Hasil Kultur & & \\
Positif & 29 & 57 \\
Negatif & 22 & 43 \\
Jumlah & 51 & 100 \\
\hline
\end{tabular}

dan kontrol negatif. Dengan menggunakan pasangan primer AFU7S-AFU7AS dan primer AFU5S serta AFU5AS didapatkan hasil positif bila terlihat pita pada 236 bp (Gambar 2).

Pada penelitian ini, dilakukan juga kultur pada semua sampel sebagai gold standard untuk pemeriksaan jamur. Kultur dilakukan di Laboratorium Mikrobiologi Fakultas Kedokteran Universitas Islam Sumatera Utara menggunakan media sabaroud dextrose agar selama \pm 2 minggu. Dari hasil pemeriksaan kultur ini didapatkan 29 sampel positif mengandung Aspergillus fumigatus (Tabel 3).

\section{Pembahasan}

Pada penelitian ini, dari 51 penderita batuk kronik ternyata didapatkan banyak sampel yang hasilnya positif mengandung jamur Aspergillus fumigatus, yaitu sebanyak 35 sampel (69\%) positif dengan metode PCR dan 29 sampel (57\%) positif dengan pemeriksaan kultur.

Hasil penelitian Bexter dkk. ${ }^{13}$, dari 108 pasien penderita cystic fibrosis, dianalisis sputumnya dan didapatkan hasilnya $30 \%$ positif Aspergillus dengan metode kultur dan $80 \%$ positif Aspergillus dengan metode PCR. Menurut penelitian Denning dkk. $^{16}$ dari 42 pasien chronic pulmonary aspergillosis yang dianalisis sputumnya dengan PCR ditemukan 30 pasien (71\%) positif Aspergillus, sedangkan dengan kultur hanya $17 \%$ positif. Dari 19 pasien ABPA, 15 pasien positif jamur Aspergillus, sedangkan dengan kultur hasilnya tidak ada yang positif.

Hasil pemeriksaan sputum yang positif mengandung jamur Aspergillus fumigatus lebih banyak ditemukan menggunakan metode PCR dibanding dengan metode kultur. Dengan teknik PCR didapat 35 sampel (69\%) hasilnya positif, sedangkan dengan teknik kultur didapatkan 29 sampel (57\%) yang hasilnya positif. Pada penelitian ini, semua hasil kultur yang positif Aspergillus fumigatus maka hasil PCR juga positif terdapat pita di $236 \mathrm{bp}$. Terdapat 6 sampel yang hasil kulturnya negatif, namun hasil PCR positif dan tidak ada hasil PCR negatif dengan hasil kulturnya positif. Perbedaan hasil antara PCR dan kultur dapat disebabkan oleh sensitivitas PCR yang tinggi. Dengan PCR, satu organisme jamur sudah dapat terdeteksi. Hasil negatif pada pemeriksaan PCR karena tidak terdeteksinya satupun organisme jamur pada sputum yang diperiksa. Hasil negatif pada kultur dapat juga disebabkan oleh jamur yang mati atau tidak berhasil tumbuh dengan baik pada media.

Pada kultur sputum, selain jamur Aspergillus fumigatus pada beberapa sampel tumbuh juga jenis jamur lain seperti Aspergillus niger. Namun, dengan PCR semua sampel yang positif Aspergillus niger tidak memberikan hasil yang positif karena primer yang digunakan spesifik

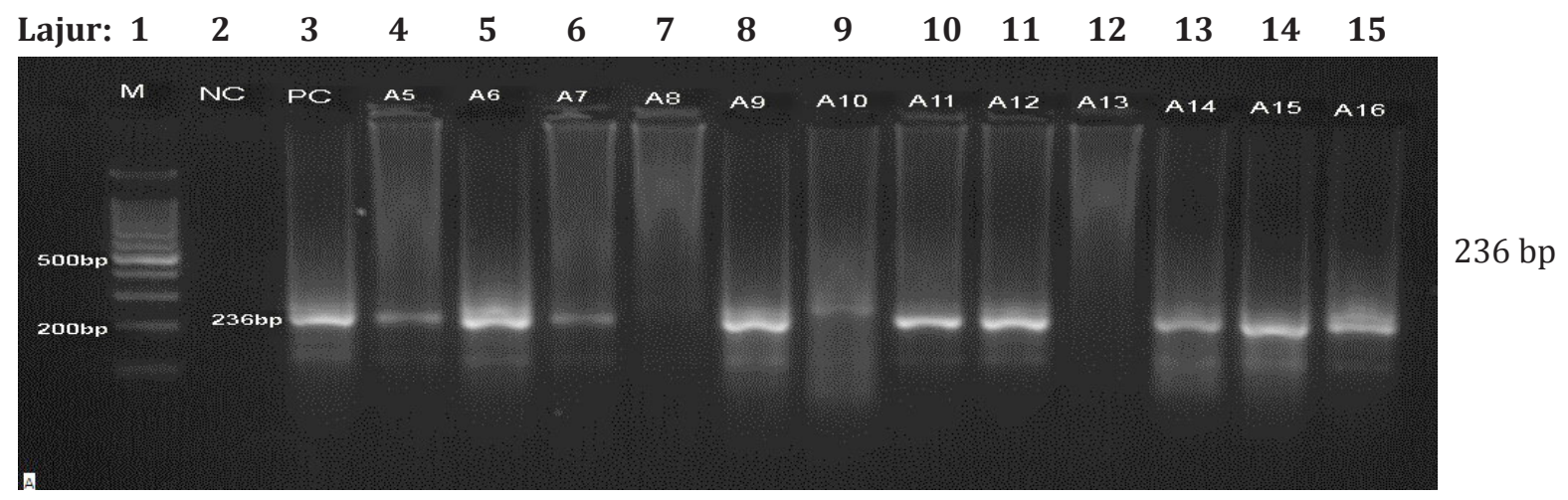

Gambar 2 Analisis DNA Produk PCR Aspergillus fumigatus Menggunakan Elektroforesis Gel Agarosa Lajur 1 = marker, lajur 2 = kontrol negatif, lajur 3 = kontrol positif, lajur 4- 5 = sampel 
untuk Aspergillus fumigatus.

Dari penelitian yang dilakukan untuk pemeriksaan jamur di Indonesia ternyata masih memakai sistem kultur yang merupakan gold standard untuk pemeriksaan jamur. Metode ini membutuhkan waktu yang lama untuk membiakkan jamur selama ( \pm 10 hari), sedangkan dengan PCR hasilnya didapatkan dalam waktu 1-2 hari. Pada beberapa penyakit diperlukan diagnosis yang cepat seperti pada penyakit meningitis, HIV/AIDS, dan imunokompromais lainnya sehingga lebih efektif bila menggunakan PCR walaupun biayanya lebih mahal daripada kultur.

Simpulan, banyak ditemukan kolonisasi jamur Aspergillus fumigatus pada sputum penderita batuk kronik baik dengan teknik kultur maupun PCR. Penyakit akibat jamur tidak dapat dianggap remeh dan harus menjadi perhatian para klinisi dan pasien diharapkan mendapat pengobatan yang cepat dan tepat untuk penyakitnya.

Teknik PCR mempunyai keunggulan karena mendeteksi lebih cepat dan tepat dibanding dengan kultur. Apabila biaya dapat ditekan maka dapat dipertimbangkan penggunaan teknik PCR dalam membantu diagnosis pada kasus yang membutuhkan hasil skrining yang cepat.

\section{Daftar Pustaka}

1. Djojodibroto DR. Respirologi (respiratory medicine). Jakarta: Penerbit EGC; 2009.

2. Rab T. Ilmu penyakit paru. Pemeriksaan Paru. Jakarta: Trans Info Media; 2010.

3. Sukamto. Pemeriksaan jamur bilasan bronkus pada penderita bekas tuberkulosis paru. Medan: Bagian Ilmu Penyakit Paru Fakultas Kedokteran Universitas Sumatera Utara, USU Digital Library; 2004.

4. Shahid M, Malik A, Bhargava R. Prevalence of aspergillosis in chronic lung diseases, Indian J Med Microbiol. 2001;19:201-5.

5. Klingspor L, Jalal S. Molecular detection and identification of Candida and Aspergillus spp. from clinical samples using real-time PCR. Clini Microbiol Infect. 2006;12(8):4553.

6. Bansod S, Gupta I, Rai M, Specific detection of Aspergillus fumigates in sputum sample of
Pulmonary tuberculosis patients by two-step PCR, African J Biotechnol. 2008;7(1):16-21

7. WHO. Laboratory manual for diagnosis of fungal opportunistic infections in HIV/AIDS patients. India: Regional Office for SouthEast Asia; 2009.

8. Zmeili OS Soubani AO. Pulmonary aspergillosis: a clinical update. Q J Med. 2007;100:317-34.

9. Raad I, Hanna H, Huaringa A, Sumoza D, Hachem R, Albitar M. Diagnosis of invasive pulmonary aspergillosis using polymerase chain reaction-based detection of Aspergillus in BAL. CHEST J American College of Chest Physicians. 2002;121:1171-6.

10. Perez CP, Buttner MP, Stetzenbach LD. Detection and quantitation of aspergillus fumigates in pure culture using polymerase chain reaction. Molec Cellular Probes J. 2005;15:81-8.

11. Hanazawa R, Murayama SY, Yamaguchi $H$. In-situ detection of Aspergillus fumigatus. J Med Microbiol. 2000;49:285-90.

12. Stevens DA, Kan VL, Judson MA, Morrison VA, Dummer S, Denning DW, dkk. Practice guidelines for diseases caused by Aspergillus. Clin Infect Dis. 2000;30(4):696-709.

13. Bexter CG, Jones AM, Webb AK, Denning DW. Real time PCR in the identification and management of aspergillus in cystic fibrosis. Thorax BMJ. 2010;65(4):A11-2.

14. Japardi I. Infeksi jamur pada susunan saraf pusat. Medan: Bagian Bedah Fakultas Kedokteran Universitas Sumatera Utara. USU Press; 2002.

15. Soyler A. Development of a PCR-based specific method for the detection of Aspergillus fumigates by random cdna cloning. Department of Food Engineering, The Middle East Technical University. 2004.

16. Denning DW, Park S, Lass-Florl C, Fraczek MG, Kirwan M, Gore R, dkk. High-frequency triazole resistance found in nonculturable Aspergillus fumigatus from lungs of patients with chronic fungal disease. Clin Infect Dis. 2011;52(9):1123-9. 